\title{
PAPARAN DEBU RESPIRABEL TERHADAP KAPASITAS VITAL PARU PADA PEKERJA DI INDUSTRI KAPUR TOHOR
}

\author{
Raudah Alfira Hayati, Zulfikar Ali As, Junaidi \\ Poltekkes Kemenkes Banjarmasin Jurusan Kesehatan Lingkungan \\ Jl. H. Mistar Cokrokusumo No. 1A Banjarbaru Kalimantan Selatan 70714 \\ E-Mail: alfirahayati@gmail.com
}

\begin{abstract}
Abstarct: Effect Of Exposure To Respiratory Dust On Lung Vital Capacity In Workers The Limestone Industry. Lime dust is one of the hazardous dust that is dangerous if left exposed. In the airways can cause airway inflammation. This inflammation can lead to obstruction of the airway so that it can reduce lung vital capacity. The purpose of this study was to determine the effect of exposure to respiratory dust on lung vital capacity in workers in the limestone industry in Kelurahan Sungai Ulin ,Kota Banjarbaru. Analytical research design with cross sectional approach. The sample in this study were all workers in the limestone industry. Data analysis used simple linear regression tests. The results of the research statistical tests showed no effect of exposure to respirate dust on the vital capacity of lung workers due to the level of dust that is still below the NAB and the normal lung condition of workers. However, it can be seen the tendency of the problem if high dust levels can reduce lung vital capacity. It is expected that with this study workers will be able to increase awareness about the use of masks when in a work environment.
\end{abstract}

Keyword: Dust Exposure; Pulmonary Vital Capacity; Limestone Industry Workers

\begin{abstract}
Abstrak: Paparan Debu Respirabel Terhadap Kapasitas Vital Paru Pada Pekerja Di Industri Kapur Tohor. Debu kapur merupakan salah satu debu respirabel yang berbahaya jika dibiarkan terus terpapar. Pada saluran nafas dapat menyebabkan peradangan jalan nafas. Peradangan ini dapat mengakibatkan penyumbatan jalan nafas sehingga dapat menurunkan kapasitas vital paru. Tujuan penelitian ini untuk mengetahui pengaruh paparan debu respirabel terhadap kapasitas vital paru pada pekerja di industri kapur tohor Kelurahan Sungai Ulin Kota Banjarbaru . Desain penelitian analitik dengan pendekatan cross sectional. Sampel dalam penelitian ini adalah semua pekerja yang ada di industri kapur tohor.Analisis data menggunakan uji regresi liniear sederhana. Hasil uji statistik penelitian menunjukkan tidak ada pengaruh paparan debu respirabel terhadap kapasitas vital paru pekerja dikarenakan kadar debu yang masih dibawah NAB dan keadaan paru pekerja yang normal. Namun dapat dilihat kecendrungan masalah apabila kadar debu tinggi dapat menurunkan kapasitas vital paru. Diharapkan dengan penelitian ini pekerja mampu meningkatkan kesadaran tentang penggunaan masker bila berada di lingkungan keja.
\end{abstract}

Kata Kunci: Paparan Debu; Kapasitas Vital Paru; Pekerja Industri Kapur

\section{PENDAHULUAN}

Debu adalah partikel-partikel zat padat yang disebabkan oleh kekuatan alami atau mekanis seperti pengolahan, penghancuran, pelembutan, pengepakan yang cepat, peledakan, dan lain-lain dari bahan-bahan, baik organik maupun anorganik, misalnya batu, kayu, biji logam, arang batu, butir-butir zat dan sebagainya. Debu dapat dihasilkan secara alami ataupun akibat campur tangan manusia. Debu dapat masuk ke dalam tubuh manusia terutama melalui saluran pernafasan. Selanjutnya debu dapat tertimbun di saluran pernafasan tergantung ukuran dan massanya. Debudebu yang berukuran 5-10 mikron akan ditahan oleh jalan napas bagian atas, sedangkan yang berukuran 3-5 mikron ditahan dibagian tengah jalan napas. Partikel-partikel yang berukuran 1-3 mikron akan ditempatkan langsung dipermukaan jaringan dalam paru-paru[1]. 
Beberapa usaha sektor informal yang erat kaitannya dengan keberadaan debu adalah pembuatan batu bata, mebel, kusen, dan batu kapur. Industri informal biasanya dikelola oleh masyarakat dengan teknologi yang masih sederhana. Penyakit paru akibat kerja merupakan salah satu penyebab utama kesakitan dan kecacatan. Sampai saat ini masih sedikit kasus penyakit paru akibat kerja yang dilaporkan.

Menurut Permenaker nomor per.13/MEN/X/2011 tahun 2011 tentang nilai ambang batas faktor fisik dan faktor kimia di tempat kerja, nilai ambang batas kalsium oksida yang dihasilkan dari proses produksi kapur adalah $2 \mathrm{mg} / \mathrm{m}^{3[2]}$.

Penelitian Hanif di perusahaan kapur gamping Guwo Lowo Puger Kab. Jember, sebanyak 12,5\% pekerja kapur gamping telah mengalami gangguan fungsi paru obstruksi. Sutra melaporkan bahwa pekerja penambang kapur di Desa Gunung Masigit yang mengalami gangguan pernapasan mencapai $56 \%$. Sedangkan $60 \%$ dari pekerja penambang kapur yang memeriksakan kesehatannya dinyataan mengalami gangguan fungsi paru berupa restriksi (baik ringan maupun sedang), obstruksi (ringan dan sedang), serta kombinasi restriksi berat dan obstruksi berat. Pekerja penambang kapur tersebut yang tidak memakai APD dan mengalami penyakit pernapasan mencapai $69,4 \%{ }^{[3]}$.

\section{BAHAN DAN CARA PENELITIAN}

Jenis penelitian ini adalah observasional analitik yang digunakan untuk mencari hubungan antar pengaruh paparan debu respirabel. Tujuan penelitian ini untuk melihat pengaruh paparan debu respirabel terhadap kapasitas vital paru pekerja di industri kapur tohor Kelurahan Sungai Ulin, Kota Banjarbaru.

Desain penelitian yang digunakan adalah cross sectional, yaitu penelitian ini menekankan pada waktupengukuran dimana variabel bebas dan terikat diobservasi hanya satu kali pada satu waktu.

Sampel penelitian ini adalah 20 pekerja yang ada di industri kapur tohor dan teknik sampel yang digunakan pada penelitian ini adalah total sampling. Pada pekerja dilakukan pemeriksaan kapasitas vital paru menggunakan spirometri.

Analisis univariat dilakukan untuk meringkas kumpulan data hasil pengukuran yang telah diteliti. Analisis bivariat dilakukan untuk mengetahui pengaruh dua variabel yaitu pengaruh paparan debu respirabel terhadap kapasitas vital paru pekerja dengan menggunakan uji regresi liniear sederhana.

Data yang diperoleh dari hasil pemeriksaan kapasitas vital paru dan hasil pengukuran debu diolah dengan software SPSS. Selanjutnya data-data tersebut dianalisis menggunakan uji regresi. Uji regresi digunakan untuk mengetahui pengaruh antara pparan debu respirabel terhadap kapasitas vital paru pada pekerja di industri kapur tohor dengan skala pengukuran numerik dan kemampuan memprediksi nilai variabel terikat jika variabel bebas sudah di ketahui.

\section{HASIL PENELITIAN DAN PEMBAHASAN}

Jumlah industri kapur tohor yang terdapat di Kelurahan Sungai Ulin Kota Banjarbaru saat ini mencapai 12 industri dengan jumlah pekerja sebanyak 20 orang. Kegiatan ini bersifat informal, kekeluargaan dan turun temurun dengan struktur organsasi yang sangat sederhana yaitu hanya pemilik industri dan karyawan. Setiap industri memiliki 2 hingga 3 orang pekerja yang bekerja setiap hari selama 8 jam. Meskipun bersifat informal, pemasaran produksi dari industri ini cukup luas. Pada saat ini industri kapur tohor di Kelurahan Sungai Ulin melayani pasar hingga ke luar wilayah Kalimantan Selatan. Dari hasil penelitian didapatan dapat datadari hasil observasi dan wawancara para pekerja di industri kapur sebagian besar berumur $<40$ tahun dan pendidikan pekerja industri kapur sebagian besar berpendidikan SMA. Masa kerja para pekerja di industri kapur sebagian besar telah bekerja lebih dari 10 tahun. Sebagian besar para pekerja di industri kapur merokok.dari 20 pekerja yang bekerja di industri kapur tidak ada 
keluhan pada pernafasan dana untuk penggunaan APD sebagian pekerja sudah menggunakan APD pada saat melakukan aktivitas pekerajaan. Status IMT para pekerja industri kapur berada di tingkat yang bagus yaitu status IMT pekerja sebagian besar normal.

Berdasarkan hasil penelitian dapat dilihat hasil pengkuran debu disetiap tahapan produksi di industri kapur dapat dilihat pada tabel 1 sebagai berikut :

Tabel 1. Paparan Debu Tahapan Produksi (mg/m³)

\begin{tabular}{|c|c|c|c|c|c|c|c|c|c|}
\hline \multirow{2}{*}{ No } & \multirow{2}{*}{ Industri } & \multicolumn{8}{|c|}{ Tahapan Produksi } \\
\hline & & 1 & 2 & 3 & 4 & 5 & 6 & 7 & 8 \\
\hline 1 & 1 & 0,005 & 0,004 & 0,008 & 0,006 & 0,008 & 0,020 & 2,241 & 2,243 \\
\hline 2 & 2 & 0,003 & 0,001 & 0,103 & 0,003 & 0,008 & 0,011 & 2,431 & 2,613 \\
\hline 3 & 3 & 0,004 & 0,002 & 0,015 & 0,118 & 0,035 & 1.503 & 1,638 & 2,541 \\
\hline 4 & 4 & 0,011 & 0,004 & 0,005 & 0,004 & 0,015 & 0,015 & 1,135 & 2,510 \\
\hline 5 & 5 & 0,005 & 0,001 & 0,008 & 0,013 & 0,005 & 1,411 & 1,122 & 2,331 \\
\hline 6 & 6 & 0,001 & 0,005 & 0,003 & 0,021 & 0,108 & 0,106 & 1,160 & 2,440 \\
\hline 7 & 7 & 0 & 0,003 & 0,011 & 0,115 & 0,003 & 1,104 & 1,352 & 2,110 \\
\hline 8 & 8 & 0,008 & 0,001 & 0,011 & 0,015 & 0,011 & 2,011 & 0,104 & 2,441 \\
\hline 9 & 9 & 0,001 & 0,004 & 0,001 & 0,004 & 0,025 & 1,150 & 0,115 & 2,630 \\
\hline 10 & 10 & 0,003 & 0,004 & 0,008 & 0,021 & 0,005 & 0,113 & 0,021 & 2,243 \\
\hline & $\begin{array}{l}\text { terangan tah } \\
\text { Bahan Baku } \\
\text { Pemgumpul } \\
\text { Pengadaan } \\
\text { kar } \\
\text { Penyusuna }\end{array}$ & $\begin{array}{l}\text { pan indu } \\
\text { dan Pe } \\
\text { han Bal } \\
\text { Batu }\end{array}$ & $\begin{array}{l}\text { mpulan } \\
\text { dan Baha } \\
\text { ur Dalar }\end{array}$ & & & & $\begin{array}{l}\text { embakar } \\
\text { embong } \\
\text { enyiram } \\
\text { engemas }\end{array}$ & an & \\
\hline
\end{tabular}

Dari tabel 1 diatas dapat dilihat debu paling rendah ada pada tahapan bahan baku dan debu paling tinggi ada pada tahapan produksi pengisian atau pengemasan pada tahap produksi bahan baku debu yang terukur adalah $0 \mathrm{mg} / \mathrm{m}^{3}$ dan pada tahapan pengisian atau pengemasan debu yang terukur paling tinggi sebesar $2,6 \mathrm{mg} / \mathrm{m}^{3}$.

Tabel 2 Hasil Pemeriksaan Kapasitas Vital Paru Pekerja

\begin{tabular}{|c|c|c|c|c|c|c|}
\hline No & Nama & FEV1 & FVC & $\begin{array}{c}\text { Persentse } \\
\text { FEV1 }\end{array}$ & Persentase FVC & Keterangan \\
\hline 1 & Pekerja 1 & 4.10 & 4.80 & $85 \%$ & $119 \%$ & Normal \\
\hline 2 & Pekerja 2 & 3.32 & 3.91 & $85 \%$ & $117 \%$ & Normal \\
\hline 3 & Pekerja 3 & 4.01 & 4.69 & $86 \%$ & $119 \%$ & Normal \\
\hline 4 & Pekerja 4 & 2.73 & 3.19 & $86 \%$ & $112 \%$ & Normal \\
\hline 5 & Pekerja 5 & 3.75 & 4.34 & $86 \%$ & $123 \%$ & Normal \\
\hline 6 & Pekerja 6 & 3.79 & 4.40 & $86 \%$ & $121 \%$ & Normal \\
\hline 7 & Pekerja 7 & 3.30 & 3.88 & $86 \%$ & $119 \%$ & Normal \\
\hline 8 & Pekerja 8 & 3.35 & 3.98 & $84 \%$ & $117 \%$ & Normal \\
\hline 9 & Pekerja 9 & 3.16 & 3.72 & $85 \%$ & $119 \%$ & Normal \\
\hline 10 & Pekerja 10 & 2.92 & 3.40 & $86 \%$ & $117 \%$ & Normal \\
\hline 11 & Pekerja 11 & 3.08 & 3.78 & $81 \%$ & $115 \%$ & Normal \\
\hline 12 & Pekerja 12 & 3.66 & 4.30 & $85 \%$ & $119 \%$ & Normal \\
\hline 13 & Pekerja 13 & 2.96 & 3.46 & $86 \%$ & $122 \%$ & Normal \\
\hline 14 & Pekerja 14 & 3.12 & 3.58 & $87 \%$ & $131 \%$ & Normal \\
\hline 15 & Pekerja 15 & 3.46 & 4.16 & $83 \%$ & $117 \%$ & Normal \\
\hline 16 & Pekerja 16 & 3.46 & 4.04 & $86 \%$ & $122 \%$ & Normal \\
\hline 17 & Pekerja 17 & 3.52 & 4.21 & $84 \%$ & $117 \%$ & Normal \\
\hline 18 & Pekerja 18 & 3.72 & 4.35 & $86 \%$ & $119 \%$ & Normal \\
\hline 19 & Pekerja 19 & 3.35 & 3.90 & $86 \%$ & $115 \%$ & Normal \\
\hline 20 & Pekerja 20 & 3.02 & 3.23 & $93 \%$ & $83 \%$ & Normal \\
\hline
\end{tabular}


Berdasarkan hasil pemeriksaan kapasitas vital paru pekerja di industri kapur tohor hasil pemeriksaan menunjukan bahwa

kapasital vital paru pekerja di industri kapur normal semua tida mengalami gangguan.

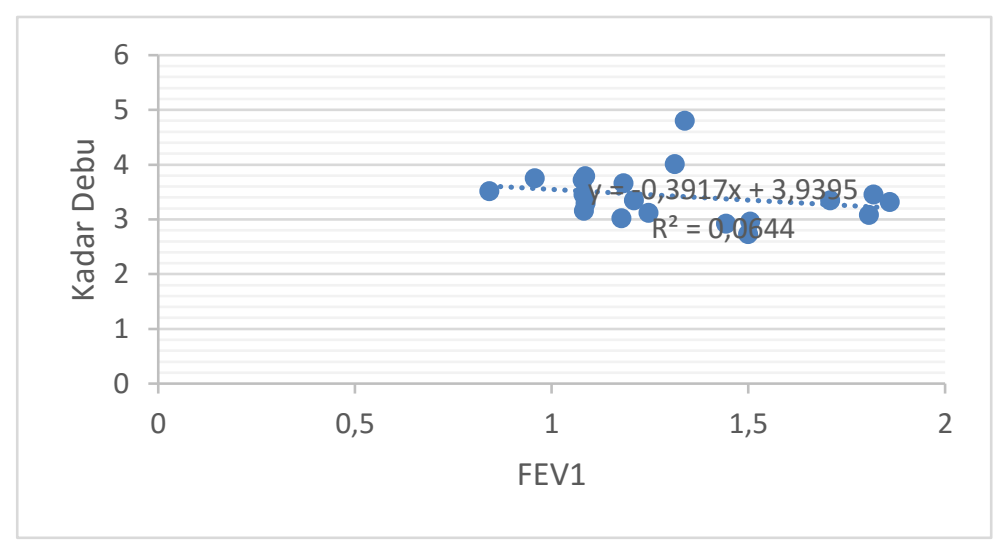

Gambar 1 Pola hubungan kadar debu dan FEV1

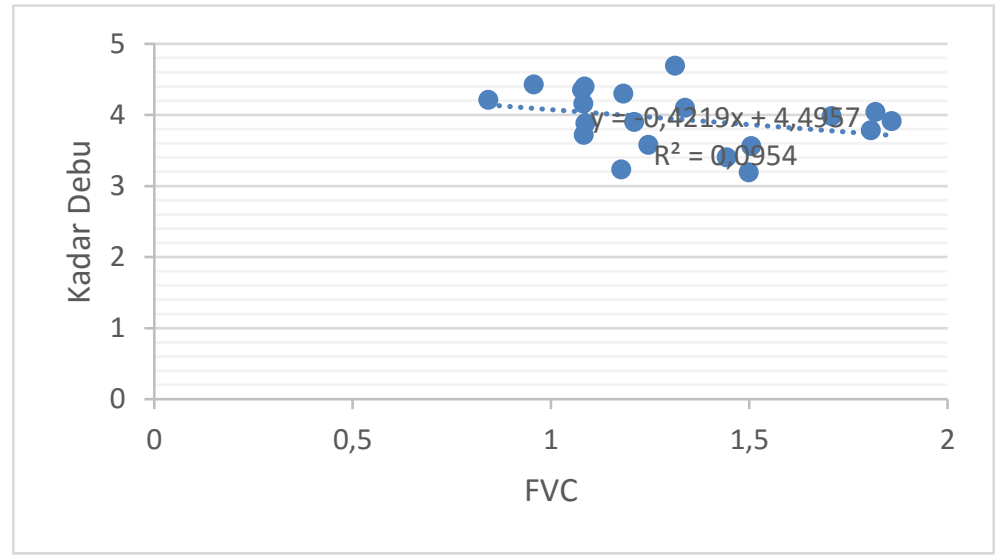

Gambar 2 Pola hubungan kadar debu dan FVC

Pada gambar 1 dan gambar 2 diketahui bahwa pada pola menggambarkan kecendrungan pada kadar debu dan parameter pemeriksaan kapasitas vital paru $\mathrm{FEV}_{1}$ dan FVC dari pola tersebut menggambarkan apabila kadar debu tinggi maka dapat menurunkan kapasitas vital paru pada pekerja.

Berdasarkan hasil uji regresi linier sederhana antara kadar debu dengan kapasitas vital paru untuk parameter FEV1 diperoleh nilai $\mathrm{p}=0,384$ sedangkan parameter FVC diperoleh nilai $p=0,417$. Hal ini menunjukkan bahwa secara statistic pada tingkat kepercayaan 95\%, kadar debu tidak ada pengaruhnya terhadap kapasitas vital paru yang diwakili oleh nilai FEV1 maupun FVC. Walaupun demikian, jika dilihat dari sebaran datanya terdapat kecenderungan korelasi negative, artinya semakin tinggi kadar debu maka semakin rendah kapasitas vital paru pekerja baik yang direpresentasikan oleh nilai FEV1 maupun FVC. Hal ini mengindikasikan bahwa kadar debu walaupun dalam jumlah kecil (di bawah NAB) dapat menurunkan fungsi paru seseorang. 


\section{KESIMPULAN DAN SARAN}

Hasil penelitian yang didapatkan pemeriksaan kapasitas vital paru pekerja menyatakan bahwa 20 pekerja di industri kapur memiliki hasil kapasitas paru yang normal hal ini sesuai dengan keadaan lingkungan tempat kerja dimana hasil pengukuran kadar debu yang terinhalasi masih memenuhi persyaratan dengan angka kadar debu yang masih dibawah NAB.

Hasil uji statistik dengan uji regresi liniear sederhana didapatkan nilai pada parameter FEV1 0,384 > dari 0,05 hasil uji tersebut tidak signifikan sehingga Ho diterima dan parameter FVC 0,417 > dari 0,05 hasil uji tersebut tidak signifikan artinya tidak ada pengaruh paparan debu respirabel terhadap kapasitas vital paru pekerja.

Untuk peniliti selanjutnya perlu dilakukan penelitian lanjutan dengan variabel yang berbeda yang tidak diteliti pada penelitian ini seperti faktor umur, penggunaan APD, dan kebiasaan merokok. Serta dilakukan pengukuran debu $\mathrm{PM}_{2,5}$ untuk mengetahui apakah ada pengaruh antara variabel tersebut dengan kapasitas vital paru.

\section{KEPUSTAKAAN}

1. Cyntia Galuh Puspita. Pengaruh Paparan Debu Batu Bara terhadap Gangguan Faal Paru pada Pekerja Kontrak Bagian Coal handling PT. PJB Unit Pembangkitan Paiton. 2011;

2. Menteri tenaga kerja dan transmigrasi republik indonesia. Peraturan menteri tenaga kerja dan transmigrasi nomor per.13menx2011 tahun 2011 tentang nilai ambang batas faktor fisika dan faktor kimia di tempat kerja. Jakarta: 2011.

3. Armaeni ED, Widajati N. Hubungan Paparan Debu Kapur Dengan Status Faal Paru Pada Pekerja Gamping. Indones J Occup Saf Heal [Internet] 2016;5(1):6170. Available from: https://ejournal.unair.ac.id/index.php/IJOSH/arti cle/view/3800

4. Hayati RA, Kesehatan $\mathrm{K}$, Indonesia R, Banjarmasin PK, Studi P, Iv D, et al. Pengaruh paparan debu respirabel terhadap kapasitas vital paru pada pekerja di industri kapur tohor kelurahan sungai ulin kota banjarbaru. 2019; 
